\title{
PENGARUH KEPERCAYAAN DAN KOMITMEN TERHADAP KUALITAS HUBUNGAN DAMPAKNYA PADA KINERJA RANTAI PASOKAN (Studi Kasus Produksi dan Distribusi Dedak pada PD Sederhana)
}

\author{
Moh. Mukhsin \\ Fakultas Ekonomi dan Bisnis Universitas Sultan Ageng Tirtayasa Serang-Banten \\ Email: muhsin-2010@yahoo.co.id
}

\begin{abstract}
The purposes of this study is to determine whether there is influence of Trust and Commitment to Supply Chain Performance with Quality of Relation as an intervening variable, Production and Distribution case study of Dedak on PD. Sederhana. Variables used in this research are trust and commitment as independent variables, Supply Chain Performance as Dependent variable, and quality of relation as intervening variable. This research used quantitative method by using descriptive research and causal research. Data from the 4 variables were analyzed by using Structural Equation Model (SEM) in Software SmartPLS (Partial Least Square) version 1.0. The number of samples used in this study were 57 respondents.Based on the result of data analysis, it can be concluded that there is positive and significant relation among trust and commitment to the quality of relation, whereas there is positif significant relation among Trust and commitment to supply chain performance. The result of analysis indicate that the quality of relation is able to mediate trust and commitment influence to supply chain performance.
\end{abstract}

Keywords: Trust, commitment, quality of relation and Supply Chain Performance.

\begin{abstract}
Abstrak: Penelitian ini bertujuan untuk mengetahui apakah ada pengaruh kepercayaan dan komitmen terhadap kinerja rantai pasokan dengan kualitas hubungan sebagai variabel intervening studi kasus produksi dan distribusi dedakpada PD Sederhana.Variabel yang digunakan dalam penelitian ini adalah kepercayaan dan komitmen sebagai variabel independen,kinerja rantai pasokan sebagai variabel dependen, dan kualitas hubungan sebagai variabel intervening. Penelitian ini menggunakan metode kuantitatif dengan menggunakan riset deskriptif dan riset kausal. Data dari keempat variabel dianalisis dengan menggunakan Struktural Equation Model (SEM) dalam Software Smart PLS (Partial Least Square) versi 1.0. Jumlah sampel yang digunakan dalam penelitian ini adalah 57orang responden.Berdasarkan hasil analisis data dapat disimpulkan bahwa pengaruh kepercayaan, dan komitmen memiliki hubungan pengaruh yang posistif dan signifikan terhadap kualitas hubungan sedangkan pengaruh kepercayaan dan komitmen terhadap kinerja rantai pasokan, memiliki hubungan pengaruh yang positif signifikan.Hasil analisis menunjukkan bahwa kualitas hubungan mampu memediasi pengaruh kepercayaan, dan komitmen terhadap kinerja rantai pasokan.
\end{abstract}

Kata Kunci: Kepercayaan,komitmen,kinerja rantai pasokan, dan kualitas hubungan rantaipasokan 


\section{PENDAHULUAN}

Manajemen rantai pasok merupakan integrasi proses bisnis, mulai dari kegiatan penerimaan bahan baku, pengelolaan di setiap mata rantai aktivitas produksi sampai siap untuk digunakan oleh pemakai. Proses rantai pasok melibatkan produsen utama, pemasok, produsen, pengecer, dan konsumen (Rajaguru dan Matanda, 2012). Rantai pasok memiliki sifat yang dinamis dan melibatkan tiga aliran yang konstan, yaitu aliran informasi, produk dan uang. Di samping itu, Chopra dan Meindl (2007) menjelaskan bahwa tujuan utama dari setiap rantai pasok adalah untuk memenuhi kebutuhan konsumen dan menghasilkan keuntungan. Simchi-Levietal. (2007) mendefinisikan SCM sebagai serangkaian pendekatan yang digunakan untuk, secara efisien, mengkolaborasikan pemasok-pemasok, manufaktur, warehouse, dan retailer sehingga mampu memproduksi dan mendistribusikan produk dalam jumlah yang tepat, lokasi yang tepat, dan waktu distribusi yang tepat. Kolaborasi yang prima dipercaya mampu meminimalisasi biaya operasional untuk mencapai kepuasan konsumen. Dalam literatur supply chain yang lain, salah satu hal yang paling penting untuk dimiliki masing-masing perusahaan dalam suatu jejaring rantai pasok adalah kepercayaan antar organisasi (Chopra \& Meindl, 2007). Kwondan Taewon (2004) menyebutkan bahwa kesuksesan pada performa perusahaan (operation performance) dalam supply chain juga berasal dari tingginya nilai kepercayaan dan komitmen yang kuat antar partner dalam supply chain. Penelitian dalam ranah strategi aliansi juga menyebutkan bahwa kemungkinan kegagalan bisa lebihbesar terjadi padahubungan dengan tingkatkepercayaan yang rendah (Kwon \&Taewon, 2004).

PD Sederhana merupakan sebuah perusahaan yang berfokus pada disribusi dan produksi dedak halus dan menir di desa Beberan Kecamatan Ciruas Banten sejak tahun1998. Semula perusahaan ini merupakan industri rumah tangga karena hanya melayani kebutuhan masyarakat sekitar dansekarang menjadi sebuah industri besar yang melayani kebutuhan masyarakat di dalam maupun di luar kota Propinsi Banten. Dalam memenuhi kebutuhan bahan baku, PD Sederhana menjalin kerjasama jangka panjang dengan banyak pemasok, skema aliran bahan baku dari para pemasok keperusahaan dapat dilihat pada gambar 1.1 dibawah,dimana setiap minggu bahan baku dipasok, namun terdapat kendala dalam kerjasama antara pemasok bahan baku dengan perusahaanya itu adanya keterlambatan dalam pemasokan bahan baku dan ketidaktepatan dalam pemenuhan kontrak supply bahan baku.

Gambar 1 berikut menunjukan skemaaliran bahan baku dari supplier kepada PD Sederhana yang bahan baku dari supplier kecil (para petani) dan penggilingan padi, disampaikan kepadasupplier besa. Selanjutnya bahan bakutersebut disampaikan kepadaPDSederhana. Bahan mentah tersebut akan diolah di PD Sederhana, kemudian hasil produksi dari PD Sederhana akan disalurkan kepada perusahaan-perusahaan besar, seperti PT cargill Indonesia, PT Agrico International, PT Cheil Jedang Superfeed, PT Sierad Produce, PT Bintang Jaya Proteina, dan lain-lain. Data pemenuhan kontrak supply bahan baku PD Sederhana pada bulan Juli hingga Desember 2016 dapat dilihat pada grafik 1 dibawah ini. 


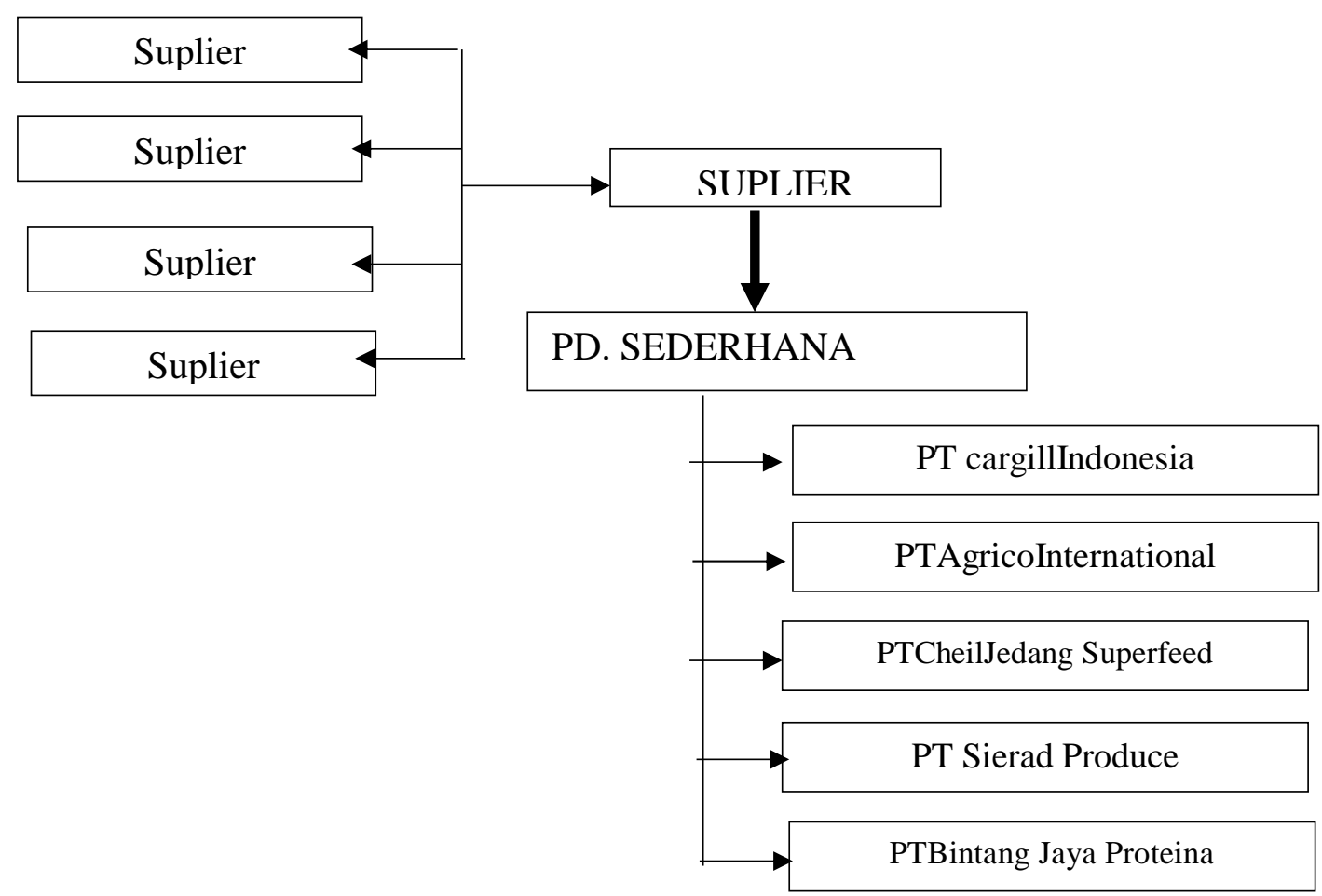

Gambar 1. Alur Rantai Pasokan PD Sederhana

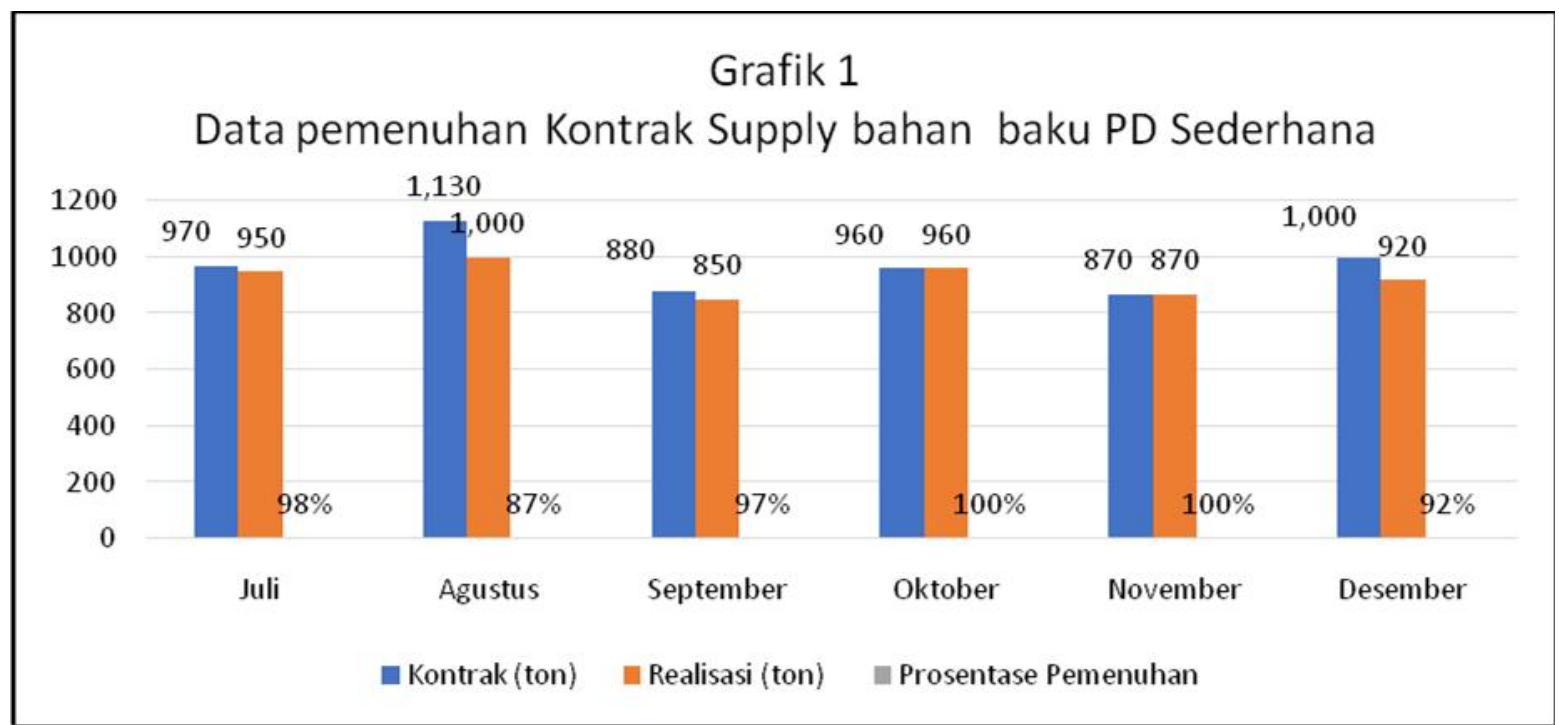

Sumber: PD Sederhana, 2016

Dari data diatas dapat dilihat secara keseluruhan pemenuhan kontrak supply bahan baku pada PD Sederhana untuk bulan Juli sampai Desember tahun 2016, dengan pemenuhan kontrak 100\% hanya terjadi pada bulan Oktober dan November. Adapun pada bulan Juli, Agustus, September, dan Desember pemasok tidak memenuhi kontrak.Hal tersebut dapat menyebabkan masalah dalam pemenuhan kuota produksi perusahaan.Grafik 2 menyajikan data tentang keterlambatan dalam memasok bahan baku dari beberapa pemasok yang telah menjalin kerja sama dalam jangka panjang. 


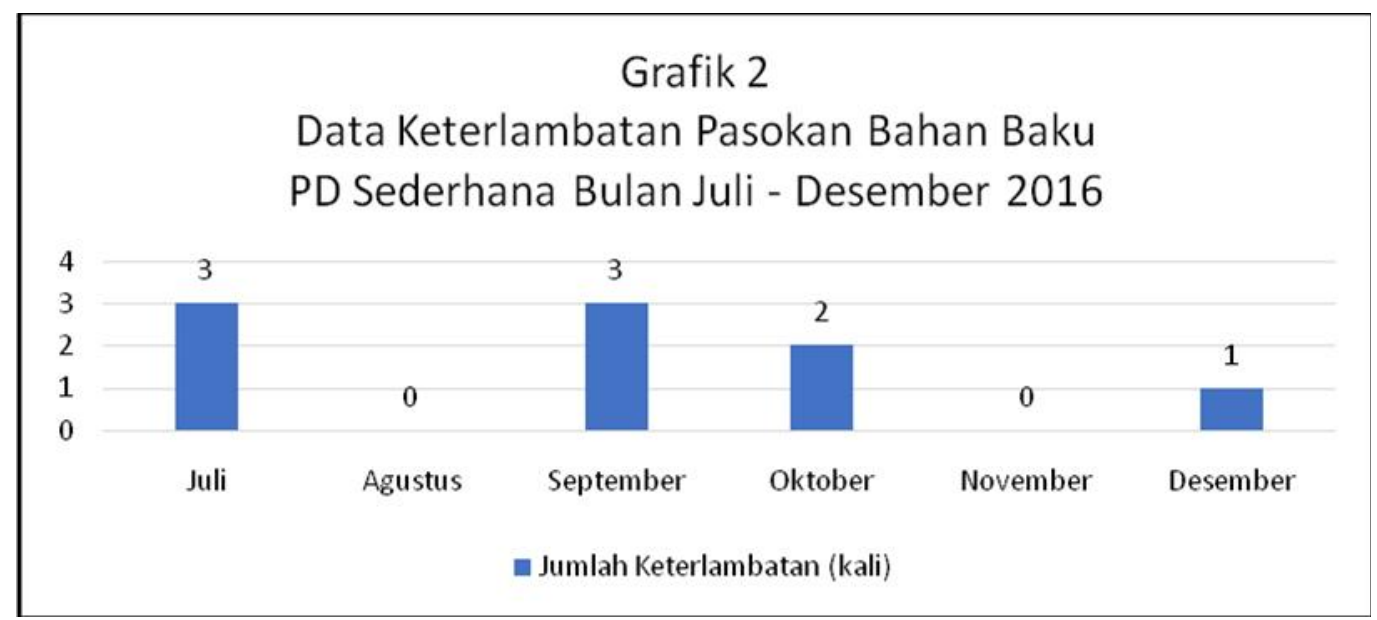

Sumber: PD Sederhana, 2016

Data grafik memberi gambaran tentang ketidaktepatan dalam menyampaikan bahan baku dari beberapa pemasok (Suplier) ke PD Sederhana. Hal tersebut dapat memberikan dampak pada kelangsungan proses produksi perusahaan.Melihat hubungan antara supplier, customer, dan perusahaan itu sendiri harus dikelola dengan baik, maka timbul pertanyaan bagaimana agar supplier ikut bertanggung jawab terhadap kualitas produk, hubungan yang baik dan jangka panjang dengan supplier dan customer. Selain itu agar distribusi produk dari hulu kehilir tepat pada waktunya sampai ke pengguna akhir. Disinilah pengelolaan perlu dilakukan. Terjadi sebuah kesalahan pada distribusi barang dan jasa akan membuat kualitas barang dan jasa menurun, dan ini berakibat daya saing melemah. Untuk meningkatkan distribusi barang dan jasa, dan pembagian informasi dari hulu kehilir pada perusahaan. Oleh karena itu diperlukan pengelolaansecara komprehensif.

Penerapan dan praktek supply chain management untuk penyediaan barang dan jasa inilah yang sangat diperlukan bagi perusahaan, dalam rangka meningkatkan daya saingindustryyang akan memberikan dampak pada kinerja usaha. PD Sederhana sangat memelihara hubungan antara suplier besar dengan PD Sederhana dan PD Sederhana dengan konsumen akhirnya yaitu perusahaan yang membutuhkan bahan produksi dari PD Sederhana. Sehingga berdasarkan latar belakang masalah tersebut yaitu adanya keterlambatan dalam pemenuhan bahan produksi dan belum sesuainya pasokan bahan produksi dengan kontrak seharusnya.

Makara (2015) menemukan kepercayaan memberikan efek yang signifikan terhadap kinerja rantai pasokan. Penelitian Mamad dan Chahdi (2013) mengkonfirmasi bahwa kepercayaan adalah faktor utama kolaborasi anggota rantai pasokan. Chandra dan Kumar (2000) lebih lanjut mengatakan bahwa kinerja rantai pasokan ditentukan oleh tingkat kepercayaan perusahaan terhadap pemasoknya, dan fleksibilitas organisasi. Sedangkan penelitian dalam ranah strategi aliansi juga menyebutkan bahwa kemungkinan kegagalan bisa lebih besar terjadi pada hubungan dengan tingkat kepercayaan yang rendah (Kwon \&Taewon, 2004).

Tujuan penelitianini adalah: (1) untuk menganalisis pengaruh kepercayaan terhadap kualitas hubungan perusahaan pemasok; (2) untuk menganalisis pengaruh kepercayaan terhadap kinerja rantai pasokan; (3) untuk menganalisispengaruh komitmen terhadap kualitas hubungan perusahaan pemasok; (4) untuk menganalisis pengaruh komitmen 
terhadap kinerja rantai pasokan; (5) untuk menganalisis pengaruh kualitas hubungan terhadap kinerja rantai pasokan.

\section{KAJIAN TEORI}

Kepercayaan.Kepercayaan (trust) merupakan pondasi dari bisnis. Membangun kepercayaan dalam hubungan jangka panjang dengan pelanggan adalahsuatu faktor yang penting untuk menciptakan loyalitas pelanggan. Kepercayaan ini tidak begitu saja dapat diakui oleh pihak lain/mitra bisnis, melainkan harus dibangun mulai dari awal dan dapat dibuktikan. Menurut Swanetal,(1998 dalam ahmadi, 2009) kepercayaan merupakan bentuk keunggulan dalam berkomitmen pada hubungan kerja sama organisasional yang muncul dari sebuah keyakinan bahwa hubungan kerja sama akan memberikan manfaat seperti yang diharapkan oleh kedua belah pihak, diukur dengan indikator keterbukaan komunikasi, berbagi informasi yang penting, kejujuran, tanggung jawab, dan pengalaman. Kwon dan Taewon (2004) menyebutkan bahwa kesuksesan pada performa perusahaan (operation performance) dalam supply chain juga berasal dari tingginya nilai kepercayaan dan komitmen yang kuat antar partner dalam supply chain. Pada suatu sistem rantai pasok, proses kemitraan didefinisikan sebagai interaksi antara komitmen, kepercayaan dan kolaborasi antar perusahaan.

Komitmen. Komitmen merupakan motivasi untuk memelihara hubungan dan memperpanjang hubungan. Komitmen harus menjadi sebuah variabel penting dalam menentukan kesuksesan hubungan. Semakin tinggi komitmen yang dibangun dari kepuasan dan kepercayaan maka semakin tinggi kualitas hubungan saluran antara pemasok dan penyalur. Komitmen merupakan motivasi untuk memelihara hubungan dan memperpanjang hubungan (Handoko, 2008). sebuah keinginan untuk berkorban secara jangka pendek dalam memperoleh manfaat jangka panjang baik hal tersebut datang dari sisi pemasok maupun sisi penyalur. Studi Wetzels et.al., (1998, dalam Handoko, 2008) menyatakan semakin tinggi komitmen yang dibangun dari kepuasan dan kepercayaan maka semakin tinggi kualitas hubungan saluran antara pemasok dan penyalur.

Kualitas Hubungan. Benton dan Maloni (2005) menelusuri asal-usul kualitas hubungan dengan pemasok dan menunjukkan bahwa itu diadopsi oleh perusahaan barat pada tahun 1990-an. Mereka menunjukan komunikasi, kepercayaan dan kerjasama sebagai pilar kualitas hubungan dengan pemasok. Kualitas hubungan dengan pemasok dapat berguna untuk meningkatkan kemampuan pemasok sehubungan dengan teknologi, kualitas, pengiriman, dan biaya. Hal ini juga mendorong perbaikan terus menerus (Sheth dan Sharma, 1997). Tungjitjarurn, et al (2012) menyatakan bahwa dimensi utama yang mencirikan pengembangan pemasok sukses akan mencakup, tetapi tidak terbatas pada pengintegrasian dan peningkatan kegiatan dan proses, kerjasama terus menerus dan hubungan jangka panjang yang saling menguntungkan sebagai akibat dari upaya perbaikan, dan struktur yang jelas bagi kedua perusahaan berkaitan dengan biaya, harga, dan keuntungan.

Kinerja Rantai Pasokan. Ronald H. Ballou et al. (2005) dalam bukunya business logistic/supplychain management mendefenisikan rantai pasokan sebagai seluruh rangkaian aktifitas (aktivitas) yang berhubungan dengan aliran transformasi barang dari tahapan bahan baku sampai ke pengguna akhir, begitupun dengan aliran informasinya. 
Material/barang bersama-sama mengalir dari hulu ke hilir dalam rantai pasokan. Adapun manajemen rantai pasokan menurut Ballou (2005) adalah integrasi dari seluruh aktifitas dalam rantai pasokan, sampai meningkatkan hubungan untuk mendapatkan keunggulan bersaing. Menurut Mentzer (dalam Ballou, 2005), manajemen rantai pasokan didefenisikan sebagai sesuatu yang sistematik, koordinasi yang strategis dari fungsifungsi bisnis tradisional dan taktik-taktik melalui fungsi-fungsi bisnis tersebut dalam sebuah perusahaan dan melalui bisnis dalam rantai pasokan, dengan tujuan meningkatkan performa jangka panjang dari perusahaan individu dan rantai pasokan sebagai keseluruhan.

\section{Kerangka Pemikiran}

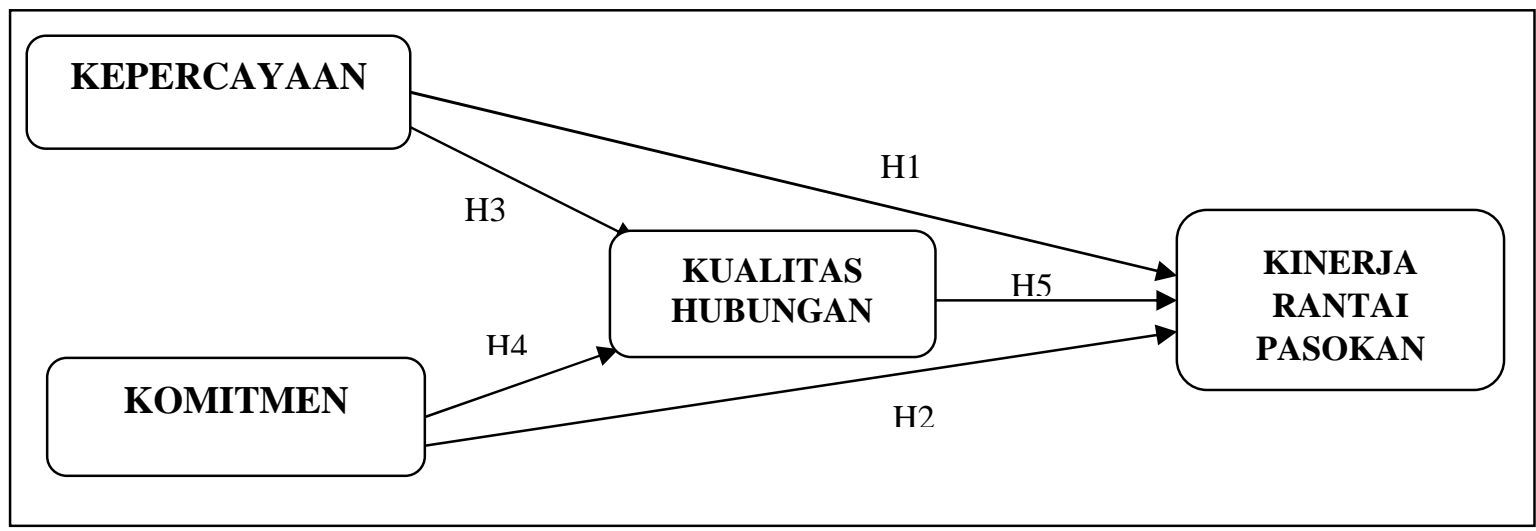

Gambar 2. Model Penelitian yang dikembangkan

Sumber : Konsep yang di kembangkan dalam penelitian ini.

\section{METODE}

Dalam penelitian ini disajikan penelitian yang bersifat causal relationship yang merupakan penentuan pada tingkat pengaruh yang dapat juga digunakan untuk melakukan prediksi. Peneliti dapat mengidentifikasi fakta atau peristiwa tersebut sebagai variabel yang dipengaruhi (varibel dependen) dan melakukan penelitian terhadap variabel yang mempengaruhi (variabel independen).

Variabel Penelitian. Variabel dalam penelitian ini terdiri dari: (1) Variabel kepercayaan diadopsi dan diadaptasi dari penelitian Ahda (2009) terdiri atas lima indikator yaitu komunikasi terbuka (KEP1), berbagi informasi (KEP2), kejujuran (KEP3), tanggung jawab (KEP4), dan pengalaman (KEP5); (2) Variabel Komitmen diadopsi dan diadaptasi dari penelitian(Morgan dan Hunt, 1994 dalam Sugiarto, 2012) terdiri atas empat indikator, Afektif (KOM1), Kontinuan (KOM2), Normatif (KOM3), dan Keyakinan (KOM4); (3) Variabel Kualitas Hubungan diadopsi dan diadaptasi dari penelitian (Hill,1994; dalam Hesti, 2013)terdiri dari lima indikator yaitu; keuntungan hubungan Kerjasama (KH1), intensitas hubungan kerja sama (KH2), antusiasme hubungan kerja sama (KH3), kejujuran (KH4), dan Fleksibilitas (KH5); (4) Variabel Kinerja Rantai Pasokan diadopsi dan diadaptasi dari penelitian (Levi, Kaminsky, Levi, 2003), terdiri dari empat indikator yaitu; 
Reliabilitas Supply Chain (KRP1), Fleksibilitas (KRP2), Biaya (KRP3), Utilitas/asset (KRP4).

Jenis dan sumber data. Jenis dan Sumber Data Penelitian ini sebagian besar menggunakan data primer yang diperoleh di lapangan. Data primer dalam penelitan ini adalah jawaban para responden tentang analisis kinerja rantai pasokan PD Sederhana. Pengambilan data dilakukan dengan menggunakan daftar kuesioner. Data sekunder yang dipergunakan dalampenelitian ini adalah data pemenuhan kontrak supply bahan baku dan data ketelambatan pemasokan bahan baku.

Populasi. Populasi adalah wilayah generalisasi yang terdiri dari dari obyek atau subyek yang mempunyai kualitas dan karakteristik tertentu yang ditetapkan oleh peneliti untuk dipelajari dan kemudian ditarik kesimpulan (Mas'ud, 2004). Populasi dalam penelitian ini adalah mitra kerja PD Sederhana.

Sampel. Sampel dalam penelitian ini menggunakan metode purposive random sampling, peneliti pertama kali menentukan bagian yang digunakan sebagai dasar sebelum melakukan pemilihan secara acak.Dalam penelitian ini yang dimaksud adalah suplier PD Sederhana. Setelah melakukan bagian secara purposive peneliti kemudian memilih secara acak (random) elemen tersebut.Metode pengambilan sampel yang digunakan adalah mengacu pendapat Slovin. Jumlah suplier secara keseluruhan (populasinya) adalah 130 suplier PD Sederhana dengan tingkat alpha sebesar 10\%. Jumlah sampel yang diperoleh sebanyak 57 suplier responden. Untuk penentuan jumlah sampel dalam penelitian ini, digunakan rumus Slovin (Sugiono, 2011) yang dirumuskan sebagai berikut:

$$
\mathrm{n}=\frac{\mathrm{N}}{1+\mathrm{Ne}^{2}}
$$

Di mana: $\mathrm{n}=$ Ukuran Sampel; $\mathrm{N}=$ Ukuran Populasi (); e = Batas kesalahan maksimal yang ditolerir dalam sampel $(10 \%)$

Dari rumus di atas, maka besarnya jumlah sampel (n) adalah sebagai berikut:

$$
\begin{aligned}
& \mathrm{n}=130=130 \\
& 1+\overline{130(0.1)^{2} 1+13} 0(0.01) \\
& \mathrm{n}=130 \underline{130} \\
& 1+1,32,3 \\
& \mathrm{n}=56,52 \quad \text { dibulatkan menjadi } 57
\end{aligned}
$$

Pengujian Hipotesis. Pengumpulan data yang dilakukan dengan pendekatan Structural Equation Model (SEM) dengan menggunakan software Partial Least Square (PLS). PLS adalah model persamaan struktural (SEM) yang berbasis komponen atau varian (variance) dan pendekatan alternatif yang bergeser dari pendekatan SEM berbasis covariancemenjadi berbasis varian. SEM yang berbasis kovarian umumnya menguji kausalitas/teori sedangkkan PLS lebih bersifat predictive model.PLS merupakan metode analisis yang powerfull (Wold, 1985 dalam Ghozali, 2006). 


\section{HASIL DAN PEMBAHASAN}

Uji Validitas. Uji validitas digunakan untuk mengukur sah atau valid tidaknya suatukuesioner. Suatu kuesioner dikatakan valid jika pertanyaan pada kuesioner tersebut mampu untuk mengungkapkan sesuatu yang akan diukur oleh kuesioner tersebut. Pengujian validitas data dalam penelitian ini adalah dengan menggunakan software SmartPLS dengan Outer Model, yaitu Convergent validity yang dilihat dengan nilai square root of average variance extracted (AVE) masing-masing konstruk yang nilainya harus lebih besar dari 0,5 (Ghozali, 2006). Cara lain yaitu dengan membandingkan nilai square root of average variance extracted (AVE) setiap konstruk (variabel laten) dengan korelasi antara konstruk dengan konstruk lainnya dalam model. Apabila nilai akar kuadrat dari AVE untuk setiap konstruk lebih besar daripada nilai korelasi antara konstruk satu dengan konstruk lainnya dalam model, maka masing-masing indikator pernyataan adalah valid (Ghozali, 2006) atau dikatakan memiliki nilai Discriminant validity yang baik.

Tabel 1. Average Variance Extracted (AVE)

\begin{tabular}{|c|c|c|c|c|c|c|c|}
\hline \multicolumn{8}{|c|}{ Average Variance Extracted (AVE) } \\
\hline Mean, STDEV, T-Values, P-Va... & 暍 & \multicolumn{2}{|c|}{ Confidence Intervals } & \multicolumn{2}{|c|}{ Confidence Intervals Bias $\mathrm{C} \ldots$} & $\begin{array}{l}\text { Samples } \\
\text { T Statistics (|O... }\end{array}$ & $\begin{array}{c}\text { Copy to Clipboard: } \\
\text { P Values }\end{array}$ \\
\hline KEPERCAYAAN & & 0.749 & & 0.758 & 0.043 & 17.323 & 0.000 \\
\hline KINERJA RANTAI PASOKAN & & 0.726 & & 0.744 & 0.052 & 14.074 & 0.000 \\
\hline KUALITAS HUBUNGAN & & 0.669 & & 0.673 & 0.054 & 12.375 & 0.000 \\
\hline
\end{tabular}

Sumber: Data primer diolah dengan SmartPLS (2016)

Tabel 1 menjelaskan nilai dari AVE dan akar AVE dari konstruk Kepercayaan, Komitmen, Kualitas Hubungan dan Kinerja Rantai Pasokan. Dapat dilihat bahwa setiap konstruk (variabel) tersebut memiliki nilai AVE diatas 0.5. Hal ini menunjukkan bahwa setiap konstruk tersebut memiliki nilai validitas yang baik dari setiap indikatornya atau kuesioner yang digunakan untuk mengetahui variabel Kepercayaan, Kommitmen, Kualitas Hubungan dan Kinerja Rantai Pasokan dapat dikatakan valid. Cara lain yang dapat digunakan untuk menilai validitas suatu konstruk adalah dengan membandingkan akar kuadrat dari AVE yang terdapat dalam Tabel 1 dengan korelasi dari variabel laten yang terdapat dalam Tabel 2.

Tabel 2. Correlations of Latent Variables

\begin{tabular}{|c|c|c|c|c|c|c|}
\hline \multicolumn{7}{|l|}{ Discriminant Validity } \\
\hline \multirow[t]{2}{*}{ Fornell-Larcker Criteri... } & Cross Loadings & Heterotrai & t-Monotrait R... 推直 & Heterotrait-Mon & notrait R... & Copy to Clipboard: \\
\hline & & KEPERCAYAAN & KINERJA RANT... & KOMITMEN & KUALITA & AS HUB... \\
\hline KEPERCAYAAN & & 0.866 & & & & \\
\hline KINERJA RANTAI PASOKAN & & 0.923 & 0.852 & & & \\
\hline KOMITMEN & & 0.919 & 0.935 & 0.865 & & \\
\hline KUALITAS HUBUNGAN & & 0.923 & 0.945 & 0.939 & & 0.818 \\
\hline
\end{tabular}

Sumber: Data primer diolah dengan SmartPLS (2016) 
Hasil yang didapat menyatakan bahwa akar AVE lebih kecil apabila dibandingkan dengan korelasi variabel laten. Hal ini dapat diartikan bahwa pernyataan dalam kuesioner dinyatakan tetap valid karena semua konstruk dalam model yang diestimasi memenuhi salah satu kriteria yang berlaku.

Uji Reliabilitas. Uji reliabilitas dimaksudkan untuk mengukur internal consistency suatu kuesioner yang merupakan indikator dari variabel atau konstruk. Suatu kuesioner dikatakan reliabel jika jawaban seseorang terhadap pernyataan menghasilkan jawaban yang sama dari waktu ke waktu. Pengujian reliabilitas data dalam penelitian ini menggunakan software SmartPLS dengan kriteria uji Composite reliability. Suatu data dikatakan reliabel jika Composite reliability lebih besar dari 0.7 (Ghozali, 2006).

Tabel 3. Composite Reliability

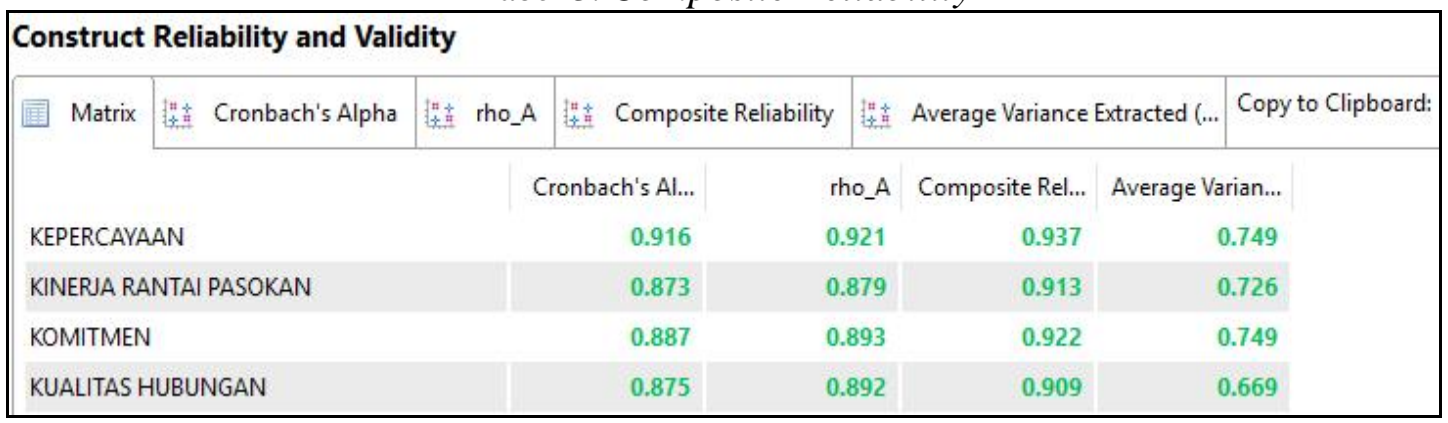

Sumber: Data primer diolah dengan SmartPLS (2016)

Dari Tabel 3 dapat dilihat setiap konstruk atau variabel laten tersebut memiliki nilai composite reliability diatas 0.7 yang menandakan bahwa internal consistency dari variabel independen (Kepercayaan, Kommitmen, dan Kualitas Hubungan) dengan variabel dependen (Kinerja Rantai Pasokan) memiliki reliabilitas yang baik.

Analisis Data. Menilai Outer Model (Measurement Model). Model measurement dilakukan untuk menguji hubungan (nilai loading) antara indikator dengan konstruk (variabel laten). Dalam menilai outer model dalam PLS terdapat tiga kriteria, salah satunya adalah melihat Convergent validity, sedangkan untuk dua kriteria yang lain yaitu Discriminant validity dalam bentuk square root of average variance extracted (AVE) dan Composite Reliability telah dibahas sebelumnya pada saat pengujian kualitas data. Untuk Convergent validity dari model pengukuran dengan refleksif indikator dinilai berdasarkan korelasi antara item score/component score yang diestimasi dengan software SmartPLS. Ukuran refleksif individual dikatakan tinggi jika berkorelasi lebih dari 0.7 dengan konstruk (variabel laten) yang diukur. Namun menurut Chin (dalam Ghozali 2006), untuk penelitian tahap awal dari pengembangan, skala pengukuran nilai loading 0.5 sampai 0.6 dianggap cukup memadai. Berikut dapat dilihat secara keseluruhan korelasi setiap variabel pada Gambar 2, yaitu gambar yang menyatakan Pengaruh Kepercayaan, Kommitmen, Kualitas Hubungan dan Kinerja Rantai Pasokan. 


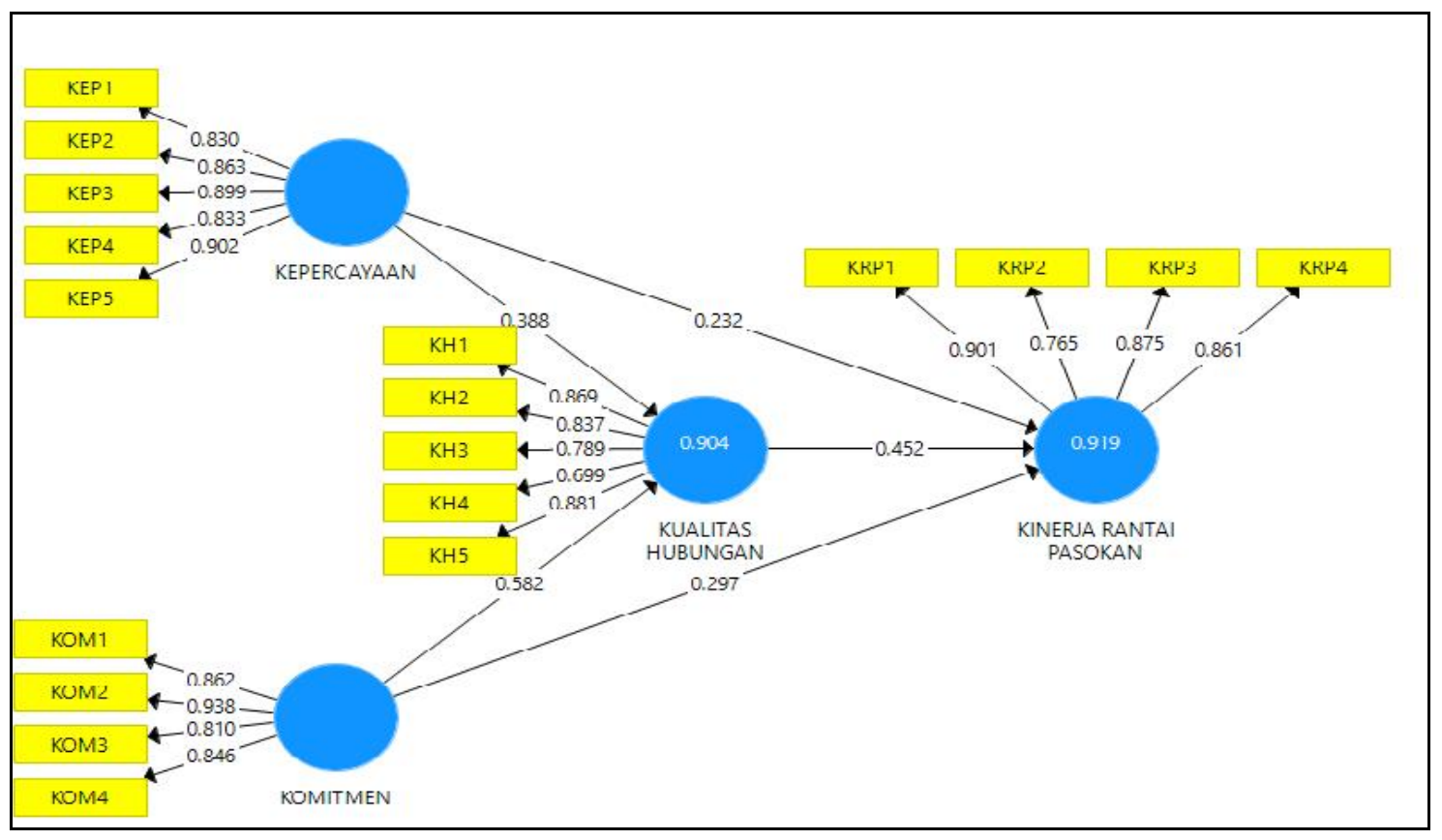

Gambar 2. Full Model Structural Partial Least Square

Sumber: Data primer diolah dengan SmartPLS (2016)

Keterangan:KEP= Kepercayaan; KOM= Komitmen; $\mathrm{KH} \quad=$ Kualitas Hubungan; $\mathrm{KRP}=$ Kinerja Rantai Pasokan

Berikut dapat dilihat secara keseluruhan korelasi setiap variabel pada gambar 2 yaitu gambar yang menyatakan pengaruh variabel independen (Kepercayaan, Komitmendan Kualitas Hubungan) dan variabel dependen (Kinerja Rantai Pasokan).

Outer Model Variabel. Dari gambar 2 Full Model Structural Partial Least Square diatas masing-masing variable dijelaskan nilai Outer Loadingsnya seperti dalam tabel 4 di bawah ini

Tabel 4. Nilai Outer LoadingsVariabel Kepercayaan, Komitmen, Kinerja Rantai Pasokan, dan Kualitas Hubungan

\begin{tabular}{|c|c|c|c|c|}
\hline \multicolumn{5}{|c|}{ Outer Londings } \\
\hline \multicolumn{5}{|l|}{ Mantrix } \\
\hline & KEPERCANYMN & KINERUA RANI... & KOMIIMEN & KUALIIAS HUв... \\
\hline KEPT & $0.8 \leq 0$ & 0.000 & o.uov & o.0uo \\
\hline KCP 2 & 0.063 & 0.000 & 0.000 & 0.000 \\
\hline KFPZ & D.pon & o.non & n.ono & o.non \\
\hline KFNA & $0.8=3$ & o.non & n.non & n.non \\
\hline KEPS & 0.902 & 0.000 & 0.000 & 0.000 \\
\hline КНТ & 0.000 & 0.000 & 0.000 & 0.809 \\
\hline $\mathrm{K} 1 \mathrm{12}$ & 0.000 & 0.000 & 0.000 & 0.037 \\
\hline $\mathrm{KII}$ & 0.000 & 0.000 & 0.000 & 0.789 \\
\hline $\mathrm{KH} 4$ & n.non & n.ono & n.non & ก.639 \\
\hline $\mathrm{KHS}$ & 0.000 & 0.000 & 0.000 & 0.881 \\
\hline KOMT & 0.000 & 0.000 & $0.86<$ & 0.000 \\
\hline KOUML & 0.000 & 0.000 & 0.938 & 0.000 \\
\hline $100 M 3$ & 0.000 & 0.000 & 0.310 & 0.000 \\
\hline KOMM4 & n.ono & n.onon & D.846 & o.non \\
\hline KRRT & n.non & 0.901 & o.non & o.non \\
\hline KRP2 & 0.000 & 0.765 & 0.000 & 0.000 \\
\hline KRHS & 0.000 & $0.8 / 5$ & 0.000 & 0.000 \\
\hline
\end{tabular}

Sumber: Data primer diolah dengan SmartPLS (2016) 
Outer Model Variabel Kepercayaan. Variabel KEP dijelaskan oleh 5 indikator penyataan yang terdiri dari KEP1 sampai dengan KEP5 ditunjukan dengan Gambar 2. Indikator dianggap reliabel jika memiliki nilai korelasi diatas 0.7. Namun dalam tahap pengembangan korelasi 0.5 masih dapat diterima (Ghozali, 2006).Hasil pengolahan dengan menggunakan Smart PLS dapat dilihat pada Tabel 4, dimana nilai outer loadings dari indikator variabel kepercayaan tidak terdapat nilai yang kurang dari 0.5 dan menunjukkan nilai outer model atau korelasi dengan variabel secara keseluruhan sudah memenuhi Convergent validity. Hal ini juga dapat dilihat pada Tabel 4, yaitu nilai tstatistik dari indikator KEP1 sampai dengan KEP5 lebih besar daripada t-tabel (dengan tingkat sig=1,96 dan $\mathrm{n}$ sampel=57). Sehingga dapat ditarik kesimpulan bahwa variabel kepercayaan telah memenuhi syarat dari kecukupan model atau Discriminant validity.

Outer Model Variabel Komitmen. Variabel KOM dijelaskan oleh 4 indikator yang terdiri dari KOM1 sampai dengan KOM4 ditunjukan dengan Gambar 2 Uji terhadap outer loading bertujuan untuk melihat korelasi antara score item atau indikator dengan score konstruknya. Indikator dianggap reliabel jika memiliki nilai korelasi diatas 0.7. Namun dalam tahap pengembangan korelasi 0.5 masih dapat diterima (Ghozali, 2006). Hasil pengolahan dengan menggunakan Smart PLS dapat dilihat pada Tabel 4, yaitu nilai outer loadings dari indikator variabel komitmen tidak terdapat nilai yang kurang dari 0.5 dan menunjukkan nilai outer model atau korelasi dengan variabel secara keseluruhan sudah memenuhi Convergent validity. Hal ini juga dapat dilihat pada Tabel 4, yang nilai tstatistik dari indikator KOM1 sampai dengan KOM4 lebih besar daripada t-tabel (dengan tingkat sig=1,96 dan n sampel=57). Sehingga dapat ditarik kesimpulan bahwa komitmen telah memenuhi syarat dari kecukupan model atau Discriminant validity.

Outer Model Variabel Kualitas Hubungan. Variabel Kualitas Hubungan dijelaskan oleh 5 indikator yang terdiri dari KH1 sampai dengan KH5 ditunjukan dengan Gambar 2 Uji terhadap outer loading bertujuan untuk melihat korelasi antara score item atau indikator dengan score konstruknya. Indikator dianggap reliabel jika memiliki nilai korelasi diatas 0.7. Namun dalam tahap pengembangan korelasi 0.5 masih dapat diterima (Ghozali, 2006).

Hasil pengolahan dengan menggunakan SmartPLS dapat dilihat pada Tabel 4, dimana nilai outer loadings dari indikator ada 4 indikator variabel kualitas hubungan tidak terdapat nilai yang kurang dari 0.5 menunjukkan nilai outer model atau korelasi dengan variabel secara keseluruhan sudah memenuhi Convergent validity. Hal ini juga dapat dilihat pada Tabel 4 nilai t-statistik dari indikator KH1 sampai dengan KH5 lebih besar daripada t-tabel (dengan tingkat sig=1,96 dan $\mathrm{n}$ sampel=57). Sehingga dapat ditarik kesimpulan bahwa variabel kualitas hubungan telah memenuhi syarat dari kecukupan model atau Discriminant validity.

Outer Model Variabel Kinerja Rantai Pasokan. Variabel kinerja rantai pasokan dijelaskan oleh 4 indikator pernyataan yang terdiri dari KRP1 sampai dengan KRP4 ditunjukan dengan Gambar 2. Uji terhadap outer loading bertujuan untuk melihat korelasi antara score item atau indikator dengan score konstruknya. Indikator dianggap reliabel jika memiliki nilai korelasi diatas 0.7. Namun dalam tahap pengembangan korelasi 0.5 masih dapat diterima (Ghozali, 2006). Hasil pengolahan dengan menggunakan Smart PLS dapat dilihat pada Tabel 4 dimana nilai outer loadings dari indikator variabel kinerja rantai pasokan tidak terdapat nilai yang kurang dari 0.5 dan menunjukkan nilai outer model atau 
korelasi dengan variabel secara keseluruhan sudah memenuhi Convergent validity. Hal ini juga dapat dilihat pada Tabel 4 , nilai t-statistik dari indikator KRP1 sampai dengan KRP4 lebih besar daripada T-tabel (dengan tingkat sig=1,96 dan n sampel=57). Sehingga dapat ditarik kesimpulan bahwa variabel kinerja rantai pasokan telah memenuhi syarat dari kecukupan model atau Discriminant validity.

Pengujian Hipotesis melalui Inner Model. Inner model menurut Ghozali (2006) merupakan gambaran hubungan antar variabel laten yang berdasarkan pada substantive theory Inner model yang kadang disebut juga dengan inner relation, structural model dan substantive theory. Pengujian inner model atau model struktural dilakukan untuk melihat hubungan antara konstruk, nilai signifikasi dan $R$-square dari model penelitian. Adapun inner model dalam penelitian ini adalah sebagai berikut:

Tabel5.Result For Inner Weight

\begin{tabular}{|c|c|c|c|c|c|c|}
\hline \multicolumn{7}{|l|}{ Path Coefficients } \\
\hline \multirow[t]{2}{*}{ Mean, STDEV, T-Values, P-Va... } & 圆 Confidence Intervals & 5 国 Confider & nce Intervals Bias $\mathrm{C}_{\mathrm{C}} .$. & ." 圆 Samples & Copy to Clipboard: & Excel Format \\
\hline & & Driginal Sampl... & Sample Mean (... S S & Standard Devia.... & T Statistics $(\mid 0 . .$. & PValues \\
\hline \multicolumn{2}{|c|}{ KEPERCAYAAN $\rightarrow$ KINERA RANTAI PASOKAN } & 0.232 & 0.222 & 0.103 & 2.257 & 0.028 \\
\hline \multicolumn{2}{|c|}{ KEPERCAVAAN - KUALITAS HUBUNGAN } & 0.388 & 0.408 & 0.120 & 3.234 & 0.002 \\
\hline \multicolumn{2}{|c|}{ KOMITMEN $>>$ KINERJA RANTAI PASOKAN } & 0.297 & 0.303 & 0.141 & 2.109 & 0.039 \\
\hline \multicolumn{2}{|c|}{ KOMITMEN $>>$ KUALITAS HUBUNGAN } & 0.582 & 0.565 & 0.123 & 4.713 & 0.000 \\
\hline \multicolumn{2}{|c|}{ KUALITAS HUBUNGAN $>$ KINERA RANTAI PASOKAN } & 0.452 & 0.460 & 0.132 & 3.424 & 0.001 \\
\hline
\end{tabular}

Sumber: Data primer diolah dengan SmartPLS (2016)

Berdasarkan Tabel 5 terlihat bahwa hubungan KEP dengan KRP positif pada koefisien $=0,232$ dengan $\mathrm{t}$ hitung $=2.257$ dan $($ Pvalue $;=0,028)$ pada $\mathrm{t}=1.96$. menunjukkan bahwa KEP berpengruh positif dan signifikan pada KRP. Hubungan KEP dengan KH positif pada koefisien $=0,388$ dengan $\mathrm{t}$ hitung $=3.234$ dan $($ Pvalue $;=0,002)$ pada $\mathrm{t}=1.96$. menunjukkan bahwa KEP berpengruh positif dan signifikan pada KH. Hubungan KOM dengan KRP positif pada koefisien $=0,3297$ dengan $t$ hitung $=2.109$ dan $($ Pvalue $;=0,039)$ pada $t=$ 1.96.menunjukkan bahwa KOM berpengruh positif dan signifikan pada KRP. Hubungan $\mathrm{KOM}$ dengan $\mathrm{KH}$ positif pada koefisien $=0,582$ dengan $\mathrm{t}$ hitung $=4,713$ dan (Pvalue;= 0,000 ) pada $\mathrm{t}=1.96$. menunjukkan bahwa $\mathrm{KH}$ berpengruh positif dan signifikan pada $\mathrm{KH}$. Hubungan $\mathrm{KH}$ dengan KRP positif pada koefisien $=0,452$ dengan $\mathrm{t}$ hitung $=3,424$ dan (Pvalue; $=0,001$ ) pada $\mathrm{t}=1.96$. menunjukkan bahwa $\mathrm{KH}$ berpengruh positif dan signifikan pada KRP.

Dalam menilai model dengan PLS dimulai dengan melihat $R$-Square untuk setiap variabel laten dependen yang ditujukkan pada Tabel 6. 
Tabel 6. R-Square

\begin{tabular}{|c|c|c|c|c|c|c|}
\hline \multicolumn{7}{|l|}{ R Square } \\
\hline \multirow[t]{2}{*}{ Mean, STDEV, T-Values, P-Va... } & \multicolumn{2}{|c|}{ Confidence Intervals } & \multicolumn{2}{|c|}{ 囯 Confidence Intervals Bias $C$.. } & \multirow{2}{*}{$\begin{array}{l}\ldots \text { Samples } \\
\text { T Statistics }(\mid 0 \ldots\end{array}$} & \multirow{2}{*}{$\begin{array}{c}\text { Copy to Clipboard: } \\
\text { P Values }\end{array}$} \\
\hline & Original Sampl... & Samp & ple Mean (... & Standard Devia... & & \\
\hline KINERJA RANTAI PASOKAN & 0.919 & & 0.933 & 0.023 & 39.512 & 0.000 \\
\hline KUALITAS HUBUNGAN & 0.904 & & 0.913 & 0.020 & 44.991 & 0.000 \\
\hline
\end{tabular}

Sumber: Data primer diolah dengan SmartPLS (2016)

Keterangan: $\mathrm{KEP}=$ Kepercayaan; $\mathrm{KOM}=$ Komitmen; $\mathrm{KH} \quad=$ Kualitas Hubungan; $\mathrm{KRP}=$ Kinerja Rantai Pasokan

Tabel 6 menunjukkan nilai $R$-square kinerja rantai pasokan 0.919 dan kualitas hubungan 0.904. Semakin tinggi $R$-square maka semakin besar variabel independen tersebut dapat menjelaskan variabel dependen, sehingga semakin baik persamaan struktural.

Pengaruh Kepercayaan Terhadap Kinerja Rantai Pasokan. Berdasarkan data yang telah diolah peneliti, hasil perhitungan menunjukkan bahwa kepercayaan berpengaruh signifikan terhadap kinerja rantai pasokan. Berdasarkan hasil penelitian tidak terdapat indikator yang dieliminasi, hal ini disebabkan karena tidak terdapat korelasi konstruk yang kurang dari 0,5 sehingga setiap variabel memenuhi kriteria convergent validity yang ditampilkan dengan nilai original sample estimate sebesar 0.232 dengan $\mathrm{t}$ hitung = 2.257dan (Pvalue; $=0,028$ ) pada $\mathrm{t}=1.96$, menunjukkan bahwa KEP berpengruh positif dan signifikan terhaadap KRP. Hal ini berarti hipotesis 1 diterima.

Hasil ini menunjukkan bahwa hipotesis 1 yang diajukan adalah variabel kepercayaan mempunyai pengaruh signifikan terhadap kinerja rantai pasokan diterima atau didukung oleh fakta empiris. Arah pengaruh memiliki nilai positif dan signifikan yang berarti bahwa kepercayaan yang semakin tinggi diantara anggota rantai pasokan dapat mendorong pada semakin baiknya kinerja rantai pasokan. Hasil penelitian ini konsisten dengan Makara (2015) dan Munizu danHamid (2016) menemukan kepercayaan memberikan efek yang signifikan terhadap kinerja rantai pasokan. Penelitian Mamad dan Chahdi (2013) mengkonfirmasi bahwa kepercayaan adalah faktor utama kolaborasi anggota rantai pasokan. Berkaitan dengan temuan ini Chopra dan Meindl, (2007) mengatakan bahwasalah satu unsur penting yang harus ada dan tumbuh dalam suatu sistem rantai pasokan adalah kepercayaan diantara anggota rantai pasokan

Pengaruh Komitmen Terhadap Kinerja Rantai Pasokan. Hasil pengolahan data menunjukkan bahwa komitmen kerja berpengaruh positif dan signifikan terhadap kinerja rantai pasokan. Berdasarkan hasil penelitian tidak terdapat indikator yang dieliminasi. Hal ini disebabkan tidak terdapat korelasi konstruk yang kurang dari 0,5 sehingga setiap variabel memenuhi kriteria convergent validity yang ditampilkan dengan nilai original sample estimate sebesar 0,3297 dengan t hitung $=2.109$ dan $($ Pvalue $;=0,002$ ) pada $\mathrm{t}=$ 1.96. Dengan demikian Hipotesis 2 diterima.

Hasil ini menunjukkan bahwa hipotesis 2 yang diajukan adalah variabel komitmen mempunyai pengaruh signifikan terhadap kinerja rantai pasokan diterima atau didukung oleh fakta empiris. Arah pengaruh memiliki nilai positif dan signifikan yang berarti bahwa komitmen yang semakin tinggi diantara anggota rantai pasokan dapat mendorong pada 
semakin baiknya kinerja rantai pasokan.Hasil penelitian ini konsisten dengan penelitianCambra dan Polo (2011) menegaskan bahwa hubungan jangka panjang membutuhkan komitmen dari pihak-pihak yang terlibat. Komitmen merupakan motivasi untuk memelihara hubungan dan memperpanjang hubungan. Komitmen harus menjadi sebuah variabel penting dalam menentukan kesuksesan hubungan. Semakin tinggi komitmen yang dibangun dari kepuasan dan kepercayaan maka semakin tinggi kualitas hubungan saluran antara pemasok dan penyalur.

Pengaruh Kepercayaan Terhadap Kualitas Hubungan. Berdasarkan hasil pengolahan data menunjukkan bahwa kepercayaan berpengaruh positif dan signifikan terhadap kualitas hubungan. Berdasarkan hasil penelitian tidak terdapat indikator yang dieliminasi, hal ini disebabkan karena tidak terdapat korelasi konstruk yang kurang dari 0,5 sehingga setiap variabel memenuhi kriteria convergent validity. Berdasarkan hasil pengolahan data menunjukkan bahwa kepercayaan berpengaruh positif terhadap kualitas hubungan yang ditampilkan dengan nilai original sample estimate sebesar0,388 dengan $\mathrm{t}$ hitung $=3.234$ dan $($ Pvalue $;=0,002)$ pada $\mathrm{t}=1.96$. Dengan demikian Hipotesis 3 diterima.

Hasil ini menunjukkan bahwa hipotesis 3 yang diajukan adalah variabel kepercayaan mempunyai pengaruh signifikan terhadap kualitas hubungan diterima atau didukung oleh fakta empiris. Arah pengaruh memiliki nilai positif dan signifikan yang berarti bahwa kepercayaan yang semakin tinggi diantara anggota rantai pasokan dapat mendorong pada semakin baiknya kualitas hubungan.Hasil penelitian ini konsisten dengan penelitian Schurr dan Ozzane (1985, dalam Soetomo, 2002)yang menyatakan bahwa tingginya kepercayaan telah meningkatkan hubungan yang terjalin. Ketika kepercayaan muncul, maka akan terjalin sebuah hubungan kejasama dengan tidak melupakan sikap jujur, ketika kepercayaan dan kejujuran ada maka terjadi peningkatan hubungan kerja sama, sehingga memberikan keuntungan bagi pihak- pihak yang terlibat dan ketika keuntungan yang didapat semakin meningkat, kualitas hubungan pun meningkat, seperti yang diungkapkan oleh Hesti (2013)yang mengungkapkan bahwa terdapat pengaruh antara kepercayaan terhadap kualitas hubungan rantai pasokan pada sektor industri tekstil.

Pengaruh komitmen Terhadap kualitas hubungan. Hasil pengolahan data menunjukkan bahwa komitmen berpengaruh positif dan signifikan terhadap kualitas hubungan.Berdasarkan hasil penelitian tidak terdapat indikator yang dieliminasi, hal ini disebabkan karena tidak terdapat korelasi konstruk yang kurang dari 0,5 sehingga setiap variabel memenuhi kriteria convergent validity. Berdasarkan hasil pengolahan data menunjukkan bahwa komitmen berpengaruh positif terhadap kualitas hubungan yang ditampilkan dengan nilai original sample estimate sebesar 0,582 dengan t hitung $=4,713$ dan (Pvalue; $=0,001)$ pada $\mathrm{t}=1.96$. Dengan demikian Hipotesis 4 diterima.

Hasil ini menunjukkan bahwa hipotesis 4 yang diajukan adalah variabel komitmen mempunyai pengaruh signifikan terhadap kualitas hubungan diterima atau didukung oleh fakta empiris. Arah pengaruh memiliki nilai positif dan signifikan yang berarti bahwa komitmen yang semakin tinggi diantara anggota rantai pasokan dapat mendorong pada semakin baiknya kualitas hubungan.Hasil penelitian ini konsisten dengan penelitian Wetzels et.al., (1998, dalam Handoko, 2008) menyatakan semakin tinggi komitmen yang dibangun dari kepuasan dan kepercayaan maka semakin tinggi kualitas hubungan saluran antara pemasok dan penyalur.Sedangkan komitmen merupakan motivasiuntuk memeliharahubungan dan memperpanjang hubungan(Handoko,2008).Hal inidiperkuatoleh penelitianyang dilakukan oleh (Sugiarto, 2012) yang mengungkapkan bahwa 
komitmen berpengaruh terhadap kualitashubungan rantaipasokan padaPT Jamu Cap Jago.

Pengaruh Kualitas Hubungan Terhadap Kinerja Rantai Pasokan. Berdasarkan hasil pengolahan data ditunjukkan bahwa kualitas hubungan berpengaruh positif dan signifikan terhadap kinerja rantai pasokan. Berdasarkan hasil penelitian tidak terdapat indikator yang dieliminasi. Hal ini disebabkan tidak terdapat korelasi konstruk yang kurang dari 0,5 sehingga setiap variabel memenuhi kriteria convergent validity. Berdasarkan hasil pengolahan data diketahui bahwa kualitas hubungan berpengaruh positif terhadap kinerja rantai pasokan yang ditampilkan dengan nilai original sample estimate sebesar 0,452 dengan $\mathrm{t}$ hitung $=3,424$ dan $($ Pvalue $;=0,001$ ) pada $\mathrm{t}=1.96$. Dengan demikian Hipotesis 5 diterima.

Hasil ini menunjukkan bahwa hipotesis 5 yang diajukan adalah variabel kualitas hubungan mempunyai pengaruh signifikan terhadap kinerja rantai pasokan diterima atau didukung oleh fakta empiris. Arah pengaruh memiliki nilai positif dan signifikan yang berarti bahwa kualitas hubungan yang semakin tinggi diantara anggota rantai pasokan dapat mendorong pada semakin baiknya kinerja rantai pasokan.Hasil penelitian ini konsisten dengan penelitian Prahinski dan Benton (2004) yang meneliti pemasok perusahaan mobil di Amerika Utara menemukan bahwa kualitas hubungan dengan perusahaan memiliki pengaruh terhadap kinerja rantai pasokanKualitas hubungan menurut Johnson (1999, dalam Susanto, 2006) merupakan gambaran kedalaman dan kedekatan sebuah hubungan antara pemasok dan penyalur. Hubungan kerjasama dengan pemasok sangat berperan menentukan kinerja bisnis perusahaan, dalam kaitanya hubungan antara perusahaan dan pemasok.

Analisis Pengaruh. Analisis pengaruh perlu dilakukan untuk mengetahui besarnya pengaruh variabel eksogen terhadap variabel endogen baik secara langsung, maupun tidak langsungtersaji dalam Tabel 7 berikut.

Tabel 7. Pengaruh Langsung, Tidak Langsung

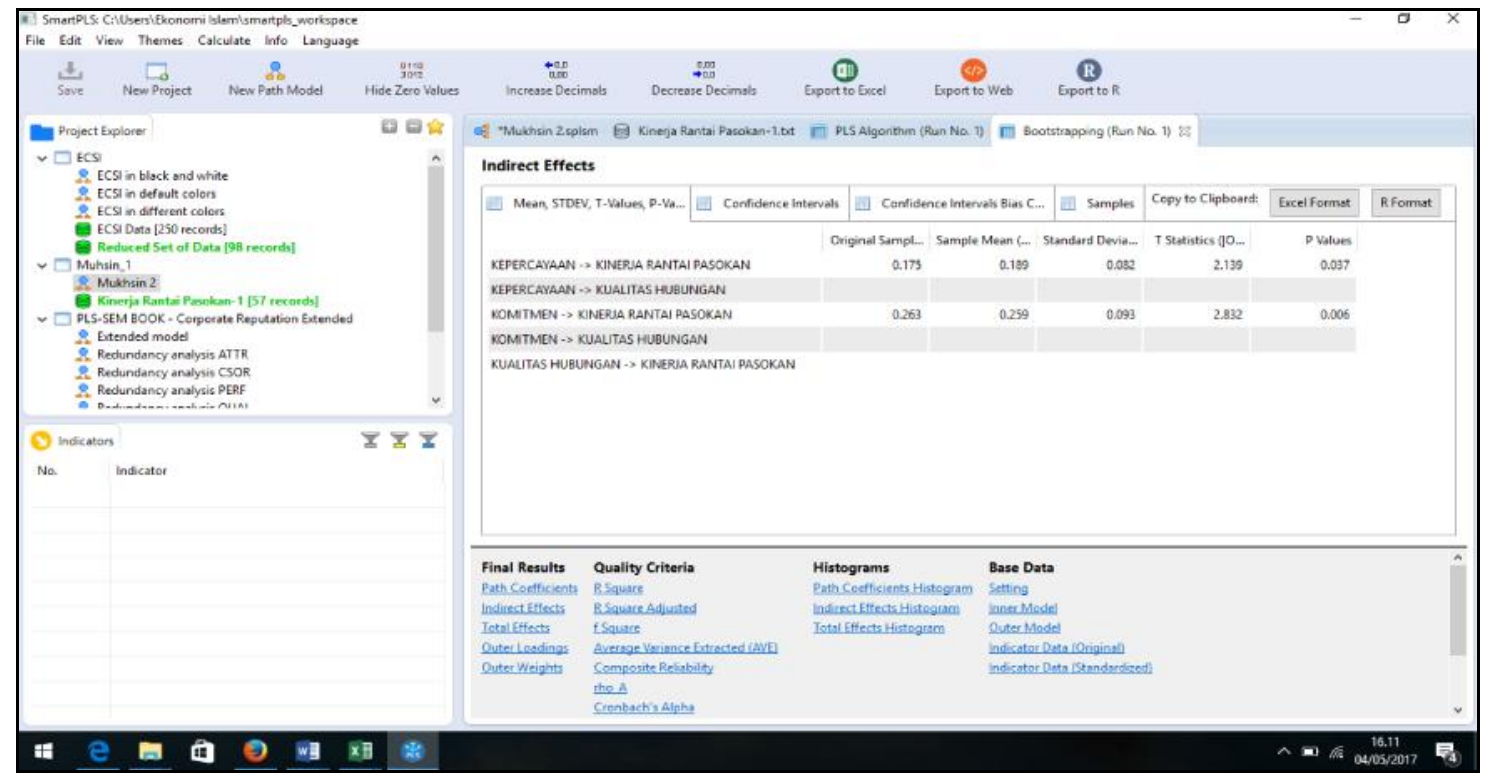

Sumber: Data primer diolah dengan SmartPLS (2016) 
Tabel 7 diatas, menunjukkan bahwa kualitas hubungan (KP) mampu memediasi pengaruh Kepercayaan (KEP) terhadap Kinerja Rantai Pasokan (KRP), berdasarkan pada t-Stat $=$ 2,139 > t-hitung sebesar 1,96 denagn pValue $=0,037<0,05$, demikian juga Kualitas Hubungan $(\mathrm{KH})$ mampu memediasi pengaruh Komitmen (KOM) terhadap Kinerja Rantai Pasokan (KRP), berdasarkan t-Stat $=2,832>$ t-hitung sebesar 1,96 dengan pValue $=0,006$ $<0,05$.

\section{PENUTUP}

Simpulan. Kepercayaan yang semakin tinggi diantara anggota rantai pasokan dapat mendorong pada semakin baiknya kinerja rantai pasokan. Kepercayaan yang semakin tinggi juga dapat mendorong pada semakin kuatnya kualitas hubungan. Komitmen yang kuat dapat mendorong pada semakin baiknya kinerja rantai pasokan.Komitmen yang kuat dapat mendorong pada semakin baiknya kualitas hubungan, Variabel kepercayaan juga mempunyai pengaruh signifikan terhadap kinerja rantai pasokan melalui kualitas hubungan. Efek tidak langsung variabel kepercayaan melalui kualitas hubungan lebih besar dibandingkan efek langsungnya dalam meningkatkan kinerja rantai pasokan, begitu pula Efek tidak langsung variabel komitmen melalui kualitas hubungan lebih besar dibandingkan efek langsungnya dalam meningkatkan kinerja rantai pasokanHasil uji analisis pengaruh menunjukkan bahwa Kualitas Hubungan mampu memediasi pengaruh Kepercayaan terhadap Kinerja Rantai Pasokan, demikian juga Kualitas Hubungan mampu memediasi pengaruh Komitmen terhadap Kinerja Rantai Pasokan.

Saran. Sesuai dengan hasil kesimpulan studi, maka dapat disarankan kepada pihak PD Sederhanadalam proses produksiperusahaan agar dapat memahami secara mendalam pentingnya membangun kepercayaan dan komitmen diantara semua anggota rantai pasokan. Peningkatan kinerja rantai pasokan hendaknya didahului dengan upaya-upaya yang intens, terencana dan kontinyu oleh semua anggota rantai pasokan untuk menciptakan dan menumbuhkan kepercayaan, dan komitmen secara bersama-sama. Kombinasi antara kepercayaan, komitmen, dan dukungan kualitas hubungan yang semakin baik akan menghasilkan kinerja rantai pasokan yang lebih tinggi.

Hasil studi ini dapat berimplikasi pada peranan manajemen yang sangat penting untuk menjaga kepercayaan, komitmen dan kualitas hubungan dalam sistem rantai pasokan. Peningkatan kinerja rantai pasokan akan ditandai dengan semakin fleksibel, dan andalnya perusahaan dalam memenuhi permintaan pelanggan. Disamping itu, pada saat yang sama kinerja pengiriman produk yang semakin baik, dan biaya operasional yang semakin menurun, serta utilitas yang optimal dalam proses operasi.Hasil penelitian ini tidak dapat digeneralisasi pada kasus lain diluar obyek penelitian ini maupun perusahaan lainnya.

\section{DAFTAR RUJUKAN}

Ahda FA. (2009)"Pengaruh bentuk rantai pasokan dan kualitas hubungan perusahaan pemasok dalam mewujudkan kinerja pemasaran melalui peningkatan kinerja rantai pasokan", Tesis, Semarang: Program Pascsarjana UNDIP.

Ahmadi. (2009) Manajemen Sumber daya Manusia. Jakarta:RinekaCipta 
Arifin, (2004) "Pengaruh Bentuk Rantai Pasokan dan Kualitas Hubungan Perusahaan Pemasok dalam Mewujudkan Kinerja Pemasaran Melalui Peningkatan Kinerja Rantai Pasokan". Jurnal Sains Pemasaran Indonesia, 3 (2), 165-180.

Benton W.C., Maloni M. (2005)“"The influence of power driven buyer/seller relationships on supply chain satisfaction". Journal of Operations Management, 23, 1-22.

Chandra C, Kumar S. (2000)"Supply chain management in theory and practice: a passing fad or a fundamental change?",Industrial Management \& Data Systems, 100(3): 100-113. https://doi. org/10.1108/02635570010286168.

Chopra, S., Meindl, P., (2007) Supply Chain Management: Strategy, Planning and Operation, third edition, Prentice Hall, New Jersey, USA.

Cambra JJ, Polo Y. (2011)"Post-satisfaction factors affecting the long-term orientation of supply relationships”, Journal of Business \& Industrial Marketing, 26 (6), 395-405. https://doi. org/10.1108/08858621111156395.

Ghozali, I. (2006)Structural Equation Modeling, Metode Alternatif dengan Partial Least Square. Badan Penerbit Universitas Diponegoro. Semarang

Chopra S, Meindl P. (2007)Supply Chain Management: Strategy, Planning, and Operation. New Jersey: Prentice-Hall, Inc.

Handoko, T.Hani. (2008)Manajemen. Yogyakarta:BPFE

Hesti Aprianingsih. (2013)“Analisis Pengaruh implementasi Teknologi Informasi Terhadap Kinerja Rantai Pasokan dengan Integrasi Rantai Pasokan Sebagai Mediator Pada Sektor Industri Tekstil (TPT)". Jurnal

Johnson, JeansL., (1999)“'Strategic Integrationin Industrial Distribution Supply Network's: Managing the Interfirm Relationship as a Strategic Asset", Journal of The Academy of Marketing Science, 27 (1), 4-18.

Kwon IWG, Taewon S. (2004)"Factors affecting the level of trust and commitment in supply chain relationships". Journal of Supply Chain Management, 40(1), 4-14. https://doi. org/10.1111/j.1745-493X.2004.tb00165.x.

Levi, D. S., P. Kaminsky, E. S. Levi, (2003)Designing \& Managing The Supply Chain, 2nd ed., McGraw-Hill Companies, Inc.

Makara. (2015)"Effects of supplier manufacturer relationships on supply chain performance of manufacturing industries in Indonesia". Journal of Technology 19(2): 51-58

Mamad M, Chahdi FO. (2013)"The factors of the collaboration between the upstream supply chain actors: case of the automotive sector in Morocco". International Business Research, 6(11), 15-28. https://doi.org/10.5539/ibr.v6n11p15.

Mas'ud, Fuad. (2014)Survai Diagnosis Organisasional Konsep \& Aplikasi. Badan Penerbit Universitas Diponegoro. Semarang.

Morgan, R.M. \& Hunt, S.D., (1994) "The Commitment-Trust Theory of Relationship Marketing”, Journal of Marketing, 58, July, 20-38

Munizu M, Hamid N. (2016)"How to improve supply chain performance by trust and commitment: study at coffee industry In Makassar, Di dalam: How innovation could improve the performance and productivity in entrepreneurship?'.Prosiding International Conference on Entrepreneurship (IConEnt-2016), Tangerang, 17 Maret 2016. Tangerang: Universitas Pelita Harapan. Hlm 559-565.

Rajaguru R, Matanda MJ. (2012)“Effects of interorganizational compatibility on supply chain capabilities".Industrial Marketing Management Journal, 1(2), 220-230. 
Ronald H.Ballou., (2004) Business Logistics /Supply Chain Management, 5 edition.(Prentice Hall 2004)

Ryu I, So S, Koo C. (2009)The role of partnership in supply chain performance. Industrial Management and Data Systems 109(4): 496-514.

Soetomo, Harsini.,(2002)"Expertise, Trust, Commitment and Behaviour Intentions in Relationship Marketing: Case Study North Bandung Dairy Cooperative", Jurnal Bisnis dan Akunansi, 4 (2).

SugiartoY. (2012) Analisis Faktor-faktor KualitasHubunganTerhadap KinerjaRantai Pasokan (Studi Kasus pada PT Jamu Cap jago Semarang).

Simchi-Levi,D.,Kaminsky,P.\&Simchi-Levi,E., (2007)Designing and Managing theSupplyChain.3Hill.

Sugiyono. (2011) Metode Penelitian Kuantitatif, Kualitatif, dan R\&D .Bandung : Alfabeta.

Tungjitjarur W., Suthiwartnarueput K., Pornchaiwiseskul P. (2012)“The Impact of Supplier Development on Supplier Performance: the Role of Buyer-Supplier Commitment, Thailand". European Journal of Business and Management, 4(16), 183-193.

Van der Vaart, Taco; Cristina Gimenez; dan Dirk Pieter van Donk, (2012) Supply chain integration and performance: the impact of business conditions, University of Groningen 